phenylbutazone, and the mechanism of interaction with warfarin is also similar. Azapropazone displaces warfarin from protein binding sites and also alters the renal clearance of $\mathrm{R}$ and $\mathrm{S}$ isomers of warfarin. ${ }^{4}$ Other non-steroidal anti-inflammatory drugs are less hazardous because they do not interfere with renal clearance of isomers of warfarin

Azapropazone is absolutely contraindicated in patients taking warfarin. This potentially hazardous interaction should be highlighted further in both the data sheet ${ }^{\prime}$ and the British National Formulary.

1 Association of the British Pharmaceutical Industry. $A B P I$ data sheet compendium 1990-1991. London: Datapharm, 1991:1378-9.

2 Powell-Jackson PR. Interaction between azapropazone and warfarin. BMf 1977;i:1193.

3 Green AE, Hort JF, Korn HET, Leach H. Potentiation of warfarin by azapropazone. BMJ 1977;i:1532.

4 Griffin JP, D’Arcy PF. A manual of adverse drug interactions. 3rd ed. Bristol: J Wright, 1984:120

5 McElnay JC, D'Arcy PF. Interaction between azapropazone and warfarin. BM7 1977;ii:773-

6 British Medical Association, Royal Pharmaceutical Society of Great Britain. British national formulary No 20. London: BMA and Pharmaceutical Press, 1990:320-3.

\section{Allergy to spiramycin during prophylactic treatment of fetal toxoplasmosis}

Drs L S Ostlere, J A A Langtry, and R C D Staughton (Westminster Hospital, London SW 1P 2AP) write: A 38 year old primagravida who was 29 weeks pregnant was admitted with a three week history of an erythematous pruritic rash. This had initially affected her hands and spread to her trunk and limbs. Eight weeks before she had been started on spiramycin $1.5 \mathrm{~g}$ twice daily for a positive maternal $\operatorname{IgM}$ titre indicating toxoplasma infection, which may have occurred up to one year before conception. Fetal blood sampling for toxoplasma antibody was negative and ultrasonography had shown no abnormality. She had a history of atopic eczema and was taking other drugs. On examination she had a widespread maculopapular rash sparing the umbilicus and forming erythematous plaques. There was no vesiculation or pustulation. The fundal height was consistent with 29 weeks' gestation. She was not feverish, and general examination was normal.

The white cell count was $11 \cdot 7 \times 10^{9} / 1$ (normal range $4-11)$ with eosinophils $2 \cdot 8 \times 10^{4} / 1\left(0-0 \cdot 4 \times 10^{\%} / 1\right)$. She had a raised $\gamma$-glutamyltransferase concentration of $82 \mathrm{U} / \mathrm{l}$ (5-55) and the other liver enzymes were normal. A skin biopsy showed focal spongiosis and occasional parakeratosis. There was dermal oedema with a moderately severe perivascular infiltrate of chronic inflammatory cells, eosinophils, nuclear dust, and occasional extravasated red cells. Results of direct immunofluorescence of affected skin were negative.

She was initially treated with beclomethasone diproprionate $0.025 \%$ (Propaderm) ointment and emollient wet wraps to good effect but relapsed when the topical steroids were stopped. Because of the temporal relation to starting spiramycin treatment, eosinophilia, raised $\gamma$-glutamyltransferase concentration, and negative results of direct immunofluorescence, the rash was thought to have been caused by allergy to spiramycin. The risk of continuing spiramycin was considered greater than the possible benefits and the drug was stopped. Over the next two weeks the pruritus and rash resolved and remained clear. Her eosinophil count fell to $0 \cdot 1 \times 10^{4} / 1$ and $\gamma$-glutamyltransferase concentration settled within the normal range. She delivered a healthy girl at 37 weeks' gestation. Her skin remained clear and at 6 weeks her daughter had normal ophthalmological findings.

Toxoplasmosis is a worldwide infection of humans and animals caused by the protozoan Toxoplasma gondii. During pregnancy toxoplasma may cause fetal infection, with potentially serious effects.' Spiramycin, one of the group of macrolide antibiotics, is thought to reduce the risk of fetal toxoplasmosis by more than half in toxoplasma infection during pregnancy. ${ }^{2}$ It has been in clinical use for 15 years with little serious associated toxicity. In the United Kingdom it is available only on a named patient basis and is used to treat toxoplasmosis and cryptosporidiosis. In other European countries it is used with similar indications to those for erythromycin. The incidence of drug rash is approximately $1 \%$ (J G Bainbridge, personal communication), the most common being a transient erythema, and one case of allergic vasculitis has been reported. ${ }^{+}$Other side effects include gastrointestinal upset and increased activity of liver enzymes.

France has had a national prevention programme for congenital toxoplasmosis since 1976. It includes mandatory serological screening of all pregnant women with monthly follow up tests if results are negative and treatment with spiramycin when acute infection is diagnosed. In the United Kingdom the prevention of congenital toxoplasmosis has received considerable attention in the mass media and the requests for antenata screening have increased. ${ }^{5}$ Spiramycin is now recommended as first line treatment in pregnancy when maternal toxoplasma infection is proved or strongly suspected. 'It is increasingly important to recognise the side effects of spiramycin.

\section{Desmonts (, , Couvreur J. Congenital toxoplasmosis: a prospective study of 378 pregnancies. N Engl f Med 1974;290:1110-6. \\ Daffos F, Forestier F, Capella-Pavlousky $M$, et al. Prenata management of 746 pregnancies at risk of congenital toxo- plasmosis. N Engl F Med 1988;318:271-5. \\ Descoters J, Vial T, Delattre D, Evreux JC. Spiramvcin: safety in man. I Antimicrobial Chemother 1988; suppl B:207-10. \\ G and $\mathrm{MC}$ Rodor $\mathrm{F}$, Jouglard J Spiramycin allergic vaculitis: first report Therapie 1987:42:227-9. \\ Anonvmous. Antenatal screening for toxoplasmosis in the UK. \\ 6 Hohlfeld P, Daffos F, Thulliez P, et al. Fetal toxoplasmosis: outcome of pregnancy and infant follow-up after in uter treatment. F Pediatr 1989;115:765-9.}

\section{Lung and skin hypersensitivity to 5-aminosalicylic acid}

Drs V le Gros, H Saveuse, G Lesur (Hôpital Ambroise Paré, 92104 Boulogne Cédex, France) and N BrION (Centre Hospitalier de Versailles, 78157 Le Chesnay Cédex, France) write: 5-aminosalicylic acid (5-ASA) is a half active component of sulphasalazine and has been used alone in the treatment of ulcerative colitis.' Sulphapyridine, a half inactive component, is held responsible for most side effects of sulphasalazine, including sulphasalazine induced lung diseases. ${ }^{2+}$ We report a case of lung and skin hypersensitivity to 5-ASA Neither the French adverse effect drug system nor the drug company have received previous reports of this.

A 54 year old woman was admitted to hospita for fever and erythematous skin rash occurring five days after treatment with 5-ASA (mesalazine) was initiated for an acute episode of ulcerative colitis ( $250 \mathrm{mg}$ oral doses three times a day). She had no history of intolerance to salicylates but 10 years previously had developed a skin rash after three weeks of treatment with sulphasalazine. A chest radiograph disclosed bilateral interstitial opacities. Lung function tests showed a carbon dioxide pulmonary diffusion capacity of $53 \%$ of the expected value. Bronchoalveolar lavage fluid contained $138 \times 10^{3}$ cells $/ \mathrm{ml}$ with $63 \%$ macrophages $1.5 \%$ eosinophils, $0.5 \%$ neutrophils, and $35 \%$ lymphocytes with a CD4/CD8 ratio of $0.95(1.70$ in blood). A blood test of basophil degranulation in presence of 5-ASA was positive at $60 \%$. 5-ASA was given for 17 days. After drug withdrawal the fever abated within 24 hours, lung opacities disappeared within 10 days, and skin rash disappeared within three weeks. One month later, the lung diffusing capacity was at $86 \%$ of the expected value.
The diagnosis of hypersensitivity to 5-ASA was based on the absence of any other aetiology; a history of hypersensitivity to sulphasalazine; lymphocytosis and low CD4/CD8 ratio in bronchoalveolar lavage fluid; blood tests positive for basophil degranulation in the presence of 5-ASA; and rapid improvement after drug withdrawal. This case suggests that 5-ASA moiety of sulphasalazine may be the responsible agent in some cases of lung diseases induced by sulphasalazine.

1 Rachmilewitz D. Coated mesalazine (5-aminosalicylic acid versus sulphasalazine in the treatment of active ulcerative colitis: a randomised trial. BMF 1989;298:82-6.

2 Jones GR, Malone DNS. Sulphasalazine-induced lung disease. Thorax 1972;27:713-7.

Thomas P, Seaton A, Edwards J. Respiratory disease due to sulphasalazine. Clin Allergy 1974;4:41-7.

Moseley RM, Barwick KW, Dobuler K, Deluca VA. Sulphasalazine-induced pulmonary disease. Dig Dis Sci 1985;30: $901-4$.

\section{Catatonia in the allopurinol hypersensitivity syndrome}

Drs C E Collins, D J B Thomas, and J M Gumpei (Mount Vernon Hospital, Northwood, Middlesex HA6 2RN) write: A 67 year old woman presented with a 24 hour history of vague affect, a widespread itchy maculopapular rash, and a temperature of $37.5^{\circ} \mathrm{C}$. She was uncommunicative, staring into space; her elbows, hips, and knees were flexed and unyielding. Eight weeks previously she had suffered a "flare up" of her longstanding gout, which was being treated with indomethacin (Indocid R $75 \mathrm{mg}$ thrice daily). At the time of admission her only medication was allopurinol $100 \mathrm{mg}$ thrice daily, which she had started six weeks previously. Her urea concentration had been $12 \mathrm{mmol} / \mathrm{l}$, serum urate concentration $609 \mathrm{~mol} / \mathrm{l}$, and haemoglobin concentration $104 \mathrm{~g} /$ when she was first prescribed allopurinol.

The following investigations were abnormal after admission: erythrocyte sedimentation rate $133 \mathrm{~mm}$ in the first hour, urea concentration $29 \mathrm{mmol} / \mathrm{l}$, creatinine concentration $391 \mathrm{mmol} / \mathrm{l}$, haemoglobin concentration $96 \mathrm{~g} / \mathrm{l}$ falling to $69 \mathrm{~g} / \mathrm{l}$ three days later. There were atypical red cell antibodies with specificity for anti-D. Tests for smooth muscle antibodies, antinuclear factor, and double stranded DNA antibodies were negative. The patient was treated with intravenous hydrocortisone $200 \mathrm{mg}$ six hourly for 48 hours, followed by oral prednisolone $40 \mathrm{mg}$ daily for two weeks; the allopurinol was discontinued. The catatonia, rash and temperature rapidly improved and the renal function returned to its previous level. The gouty arthritis was successfully treated with tiaprofenic acid, which is a uricosuric non-steroidal antiinflammatory drug. The patient remained well without taking steroids.

The allopurinol hypersensitivity syndrome is a rare, life threatening complication that usually affects patients who are also being treated with diuretics, particularly patients with impaired renal function. ' 2 Catatonia has not been described with this syndrome and its presence is difficult to explain. There was no previous psychiatric history in this patient, and allopurinol does not have any known neuroleptic activity. ${ }^{3}$ Whatever the aetiology of the catatonia in this patient, it seemed to be sensitive to steroids, improving within two hours and disappearing within 10 hours when intravenous hydrocortisone was given. Paradoxically, prednisolone was incriminated as a causative factor when catatonia developed in a patient with myeloma

1 Mills RM Severe hypersensitivity reactions associated with allopurinol. FAMA 1971;216:799-802.

Young JL, Boswell RB, Nies AS. Severe allopurinol hyperensitivity. Arch Intern Med 1974;134:553-8.

Fricchione GL. Neuroleptic catatonia and its relation to psychogenic catatonia. Biol Psychiatry 1985;20:304-13.

Grigg JR. Prednisolone mood disorder with associated catatonia. f Geriat Psychiatry Neurol 1989:2:41-4. 